\title{
Dharma Pawayangan: Transliteration, Translation, And Cultural Values Analysis
}

\author{
I Nengah Duija ${ }^{1}$, Ni Made Ayu Susanthi Pradnya Paramitha ${ }^{2}$ \\ ${ }^{12}$ Universitas Hindu Negeri I Gusti Bagus Sugriwa Denpasar ${ }^{12}$ \\ ${ }^{1}$ nengahduija@uhnsugriwa.ac.id, ${ }^{2}$ santhipradnya@uhnsugriwa.ac.id
}

\begin{abstract}
As time changes, the Balinese wayang (shadow puppet show) performances has undergone changes marked by the emergence of new plays. This study examines the lontar (traditional scripture) of Dharma Pawayangan through a manuscript study since the Dharma Pawayangan Lontar contains information and instructions on traditional puppetry art which can be used as the basis for aesthetic understanding of Balinese puppeteers today. To avoid being crushed by the secularization of new wayang creation, thus resulting in the retainment of its religio-magic nature. This study aims to determine the transliteration and translation of Dharma Pawayangan B text, and its cultural values. Another goal is to produce puppetry literary texts that are a source of inspiration for Balinese puppet masters. The result of this research is the Dharma Pawayangan B, transliterated into Latin characters and translated into Indonesian. This manuscript contains information on puppets, puppetry, and the aspects that must be understood by the dalang, namely kiwa tengen, ethics, taboos, equipment, theology, rituals, and punishment for violation of the rules, as well as the development of wayang in the modern era.
\end{abstract}

Keywords: Shadow Puppet Show; Shadow Puppet Mastery; Script; Language; Value

\begin{abstract}
Abstrak
Seiring perubahan zaman seni pertunjukan wayang Bali, telah mengalami perubahan ditandai dengan munculnya wayang-wayang garapan baru. Penelitian ini mengangkat tentang lontar Dharma Pawayangan melalui kajian pernaskahan dengan alasan utama bahwa teks yang dikandung dalam naskah lontar Dharma Pawayangan berisi informasi dan petunjuk tentang ilmu pedalangan tradisional yang dapat dijadikan dasar pemahaman estetik bagi seniman pedalangan Bali saat ini, agar tidak digerus sekularisasi dalam penciptaan wayang-wayang garapan baru, sehingga hasil garapannya masih bernilai religio-magis. Penelitian ini bertujuan untuk mengetahui alih aksara dan alih bahasa teks Dharma Pawayangan B, dan nilai budaya yang terkandung di dalamnya. Tujuan lain yakni untuk menghasilkan teks sastra pedalangan yang menjadi sumber inspirasi bagi seniman dalang Bali. Hasil penelitian ini berupa naskah lontar Dharma Pawayangan B. Naskah ini dialihaksarakan ke dalam huruf Latin, dialihbahasakan dalam bahasa Indonesia. Naskah ini memuat tentang pewayangan, pedalangan, dan aspek-aspek yang harus dipahami oleh dalang yakni kiwa tengen, etika, pantangan, perlengkapan, teologi, ritual, dan sanksi yang akan diterima jika melanggar, serta perkembangan wayang pada era modern saat ini.
\end{abstract}

Kata Kunci: Pewayangan; Pedalangan; Aksara; Bahasa; Nilai 


\section{Introduction}

Bali, as one of the ethnic groups in Indonesia, has interesting artistic and cultural characteristics. Therefore, Bali remains attractive for foreign tourists to visit and to witness the integration of cultural aesthetics inspired by Hinduism. Henceforth, Bali is famous and dubbed as the Paradise Island, the Paradise created, the Island of a Thousand Temples, the Island of Tourism and other names. Talking about art in Bali, since the relationship between Hinduism and art cannot be separated, it can foster a very deep sense of art in various fields, especially in the fields of sculpture, gamelan art, painting, dance, decorative arts and others. Therefore, in understanding Balinese culture it cannot be separated from its basic foundation, which is the source of the creation of various works of art that have existed and developed in Bali. Balinese art and culture that has developed since the arrival of tourists to Bali is growing rapidly in various forms that allow the emergence of attraction among tourists. Bali, which has quite unique and complex aesthetic elements, causes the appeal of Bali as a tourist destination to become increasingly global. In order to fully understand and evaluate the artistic endeavors of a nation, it is not enough just to analyze the forms of its art, its literature, its sound, its dances, and its visual arts. An understanding of the lifestyle, beliefs, and structure of the livelihood and life of a society are very important as the pillars of its art form and thus vital to be studied with sympathy and in an orderly manner in order to be able to carry out an appropriate interpretation and review. The shadow ritual in animism and dynamism serves as worship of "Hyang". The worship of "Hyang" is the worship of ancestral spirits, believed to be able to interfere with human life. This worship of ancestral spirits has been a cultural and religious practice in Indonesian society since pre-Hindu times (Seramasara, 2019).

Reviewing the wayang tradition development history in Indonesia and especially in Bali, we found that wayang is not something new. Its history is rooted from the ancient Balinese era as mentioned in the several inscriptions mentioned above. Given the wide and interesting study of wayang and its performance in Indonesia and especially in Bali, several experts have conducted studies in this field. In the book Geliat Seni Pertunjukan di Bali, there is a brief mention the art of wayang and its dynamics. The book is important in understanding the dynamics of the art of wayang theatre that uses Dharma Pawayangan as the main guidance (Dibia, 2012). An article entitled "Srimpi Nadheg Putri: Transformasi Naskah Menjadi Bentuk Tari Tradisi Pura Pakualaman" further strengthens the study of scripture as its main source of analyzis (Kusmayati, 2013). The article Komodifikasi Seni Pertunjukan Wayang dalam Perspektif Budaya Pop used to strengthen the understanding of the wayang' dynamic in the pop culture domain, where Dharma Pawayangan is started to be neglected in contemporary wayang paradigm (Hendro, 2013).

The concept of Dharma pawayangan stems from Old Javanese language, Dharma and pawayangan. Zoetmulder explained that the word Dharma is absorbed from Sanskrit which has many meanings, namely something that is determined or confirmed; law; habit; procedures or behavior determined by custom; obligation; Justice; virtue; customary manners; religion; good job; Buddhist laws or doctrines; a clear form or state of reality; character; disposition; character; character; distinctive features; efficacy; characteristic. In the Old Javanese language, the word Dharma can mean rules and behavior, determined by divine rules and revealed in religious law; pre-determined life course; law or code of obligation; virtue; kind; Justice; chastity; piety; generosity; the doctrine of Buddhism; character; disposition; efficacy; foundations related to religion, temples, monasteries, hermitages, and so on (Zoetmulder \& S.O. Robson, 1994). Furthermore, Zoetmulder stated that the word pawayangan (wayang performance) stems from the word wayang which can mean performance (dramatics) which tells a story using puppets or dancers; wayang character or the 
puppet itself. The root word wayang imbued with the confix pa-an into pawayangan which means a place to perform wayang; or a set of wayang puppets. Transliteration means the activity of changing from the source character to the target character by relying on word separation, spelling, and the use of diacritics. The spelling standard used was based on Old Javanese-Indonesia Dictionary by Zoetmulder and Robson. Meanwhile, translating is all forms of activities to transform a set of information or message from source language to target language.

Globalization and modernization have brought about various fundamental changes for Balinese people in various domains of life, namely religion, social, culture, economy, politics, language, and the arts. Two decades ago, Sujana stated that Balinese society was being hit by an increasingly intensive process of secularization, which had implications for the growing phenomenon of desacralization, an increasing number of cultural objects that were no longer considered sacred and had magical religious value (Naya Sujana, 1994). These changes being experienced and carried out by Balinese people today is also happening in the art world, including Balinese puppetry. Today's Balinese puppetry arts activities are strongly influenced by the tug-of-war between Balinization and globalization. The implication is that, on the one hand, new puppets appear, from creations/innovations to experimental/contemporary ones (Dibia, 2012).

Therefore, this study analyzed the lontar Dharma Pawayangan through literary study since text contains information and guidance on traditional wayang discipline which can be used as the basis for aesthetical understanding for puppet masters in Bali in avoiding the effect of secularization in writing new plays and maintaining the regious magical nature of the plays. This study aims to understand the transliteration and translation of the Dharma Pawayangan B text and to understand its cultural values.

\section{Method}

This study uses a qualitative approach by using data sources in the form of texts and scripts of Dharma Pawayangan. This research is qualitative research with a thematicphilosophical approach whose data is collected through literature study and direct observation, as well as interviews. The important characteristics of the qualitative method are (1) Focusing on the meaning and message according to the nature of the object, namely as a cultural study, (2) prioritizing the process compared to the research results so that meaning is always changing, (3) there is no distance between a researcher with the object of research, the researcher is as the main instrument, so there is a direct interaction between them, (4) the design and research framework is temporary because the research is open, (5) research is natural, takes place in of their own sociocultural contexts (Ratna, 2006). This qualitative research will be supported by the method of content analysis. The content in the content analysis method consists of two kinds, namely latent content and communication content. Latent content is the content contained in documents and manuscripts, while the content of the communication is the message contained as a result of the communication that occurs. Latent content is the content as intended by the author, while the communication content is the content as manifested in the relationship between the manuscript and the user (Ratna, 2006). The implementation of this method seems to move towards both communication and latent aspects.

The type of data used in this research is qualitative data. Qualitative data is data expressed in the form of sentences, words, pictures, and photos (Sugiyono, 2007). In this study, the types of data are mostly sentences, expressions, words from various data sources. The primary data source of this research is the text of the Dharma Pawayangan manuscript. Then in addition to primary data, secondary data is also used, namely data obtained indirectly 
from various books, research results, documents, and so on. The data used in the research are inscription notes, articles in various books, cultural journals, and so on. According to Lofland, the main data sources in qualitative research are manuscripts in the form of papyrus, stones, and the rest are additional data such as documents and others (Moleong, 2005). The main data source of this research is the primary data source obtained from the lontar library. While secondary data sources are books, articles, written documents, and so on from libraries or other places. Data collection was carried out in two steps, the first was through a library study. According to Mulyana, literature study of documents can complement the data obtained from observations and interviews. These literatures and documents can help researchers to examine other secondary sources, because most of the situations studied have a history, so these documents often describe these situations in this study. The literature, in this case, can be in the form of books, school documents, religious texts, and so on related to the research (Mulyana, 2000). Data collection is also done through interviews. This is necessary to obtain the responses from the puppetmasters regarding the relationship between Dharma Pawayangan and the development of wayang in the modern era. The instruments used in this research are all the tools used to collect data. In qualitative descriptive research, a researcher is usually the main key in collecting the necessary data. In this study, the researcher also acts as a research instrument. Moleong emphasized that in qualitative research the researcher alone or with the help of others is the main data collection tool. Researchers as instruments, in this case, can be supported by various data collection tools, such as interview guidelines, recording devices, etc. (Moleong, 2005).

Philological and literary methods were used in analyzing the data of this study. The Dharma Pawayangan text, which was originally presented in Balinese script, was translated into Latin script using a transliteration technique, text criticism was then carried out in order to explore the history of the text and the relationship between the text and the cultural background contained in the Dharma Pawayangan text by applying text criticism methods and editing techniques. The text of Dharma Pawayangan which was originally written in KawiBali language was translated into Bahasa Indonesia using the idiomatic translation method. The Dharma Pawayangan text is described and analyzed as a whole by using the structural method, followed by expanding the description and systematic analysis of the values contained in the Dharma Pawayangan text for its supporting community using hermeneutic methods and descriptive-analytic techniques. Because the data that has been collected from the results of field research are in the form of words and not a series of numbers, the form of analysis uses a descriptive-qualitative approach that is compiled into an expanded and indepth text. All of these analytical activities are meaning analyzes that consider the meaning behind social facts found in the field and also in the literature (Muhadjir, 2002).

Therefore, the steps used in this analysis are as follows: (1) Data reduction, which is a selection process, with a focus on simplification, abstraction, and transformation of rough data, obtained from various written notes in the field. So, data reduction is a form of analysis that sharpens, categorizes, directs, discards unnecessary data, and organizes data in such a way that it is expected to arrive at valid conclusions; (2) Data Presentation is part of the analysis to compile or manage the information that enables the drawing of conclusions and follow up action. The presentation of the data used in this study is in the form of a narrative which is equipped with a related network. After that, the interpretative analysis stage was carried out on all the information or data obtained. This interpretation is an activity that tries to find the meaning behind the facts, so that the observed phenomena can have value in the life of the wider community. Thus, it is expected to be able to compile information in a sequence, which is easy to understand with scientific characters. (3) Conclusion Drawing, from the beginning of the data collection, researchers have started looking for the meaning of 
words, noting patterns, explanations, causal paths, and proportions. After looking at the results of the analysis, this research activity is finally closed by drawing a final unabridged conclusion.

The theory used in this research is philology which is based more on the characteristics of the Dharma Pawayangan text than tracing the original text due to the conditions of Balinese manuscripts which do not always allow the application of the Stemma Method. Mainly because there were no common errors found in the Dharma Pawayangan script which was found as the basis for the Stemma Method due to linguistic symptoms, the birth of a manuscript from a number of main texts or contamination scripts from the horizontal copying process, as well as the strong influence of oral and literacy factors in life. literature in Bali. The research is directed to determine the authoritative manuscript, namely the manuscript that is considered the best of all existing manuscripts, especially in terms of content and language. (Djamaris, 2002). Therefore, at the text editing stage we prioritize a complete description of the manuscript, an appropriate critical apparatus, including material such as concordant, and considering that the text is usually also a witness to a particular tradition at a specific time in a typical place rather than a mix and match textual construction (Abdullah, 1991; Kratz, 1981; Soeratno, 1991; Teeuw, 1988).

The method used in text editing is the standard method by doing the followings, transliterating the text, correcting errors, making notes of corrections or changes, providing comments and interpretations, and dividing the text into categories (Djamaris, 2002). For the time being, there are 2-3 Dharma Pawayangan scripts that the research team has found. All scripts of Dharma Pawayangan will be described using a descriptive method, namely describing matters relating to the manuscript, such as the material of the manuscript, the size of the manuscript, the number of manuscript sheets, language, writing, state of the manuscript, colophons, and an outline of the contents of the manuscript. Furthermore, the Dharma Pawayangan manuscripts are compared by looking at several aspects contained in each manuscript for consideration (recentio) and for elimination of the manuscript. The method used is a comparison method. In this case, the task of the researcher as a philologist is to present a text that can be read or understood through its presentation and interpretation (Robson, 1994) or make text material more useful as it comes in a more harmonious form (Jones, 1980; Soeratno, 1991).

\section{Results and Discussion}

\section{Some Notes on Wayang and Dharma Pawayangan}

J.L.A Brandes said that long before the entry of Hinduism into the archipelago, our ancestors had 10 elements of an original culture. The ten elements of culture are: (1) Wayang (Shadow Puppet), (2) Gamelan (Traditional Orchestra), (3) Rhymes Science, (4) Traditional Batik Dying Technique, (5) Metal Works, (6) Monetary System, (7) Science Of Sailing, (8) Astronomy, (9) Farming, (10) Regulated Governance (in Rata,1996:85). Based on Brandes's opinion, it can be estimated that the "Wayang Culture" in Indonesia has developed since prehistoric times. The oldest record that mentions the existence of wayang performances in Central Java is in the Jaha Inscription which is dated $840 \mathrm{AD}$, the wayang performance at that time was called aringgit (Monografi Bali, 1976:112). The term ringgit comes from the word ringgi in Ancient Javanese which means movement, haringgit means Wayang play. During the reign of King Dyah Balitung there was an inscribed stone that mentioned the word mawayang which means puppet show. This inscribed stone is dated $907 \mathrm{AD}$. According to the oldest inscription in Bali, the Bebetin AI inscription dated 818 aka or 896 AD, mentions a puppet show in Bali, line 5: .... pande mas, pande besi, pande tembaga, pemukul (Gamelan musicians), pagending (Singers), perpadaha (tukang kendang, pabangsi (rebab mucisians), 
patapukan (Masked Dancers), parbwayang (Wayang), this inscription was made during the reign of Ugrasena (Goris,1954:54). The Tengkulak A inscription dated caka 945 mentions the name of King Sri Dharmawangsawardhana Marakatha Pangkajastanottunggadewa. On line 7A.5. there is a mention of the word ....pirus mênmênatapukan abanwal aringgita ... etc. which means clown, plays, mask, wayang. Then in the Blantih/Sangsit A inscription. Dated caka 980 which mentions the name of the king Anak Wungsu, in the $\mathrm{Vb}$ section it is mentioned:... hana banwal, atapukan, aringgit, pirusmênmên... etc, which means comedian, masked dancer, wayang, clown, and theater. Still in the reign of Anak Wungsu, in Manikliu AII inscription. In part III A.4 is mentioned ....yan atapukan, abanwal, aringgit.etc. which means masked dancer, comedian, wayang. In the undated Manikliu BII inscription in part Iib.6 is mentioned... yan atapukan, abanwal, aringgit. Which means masked dancer, comedian, wayang (Sedyawati, 1997).

\section{The Transliteration and Translation of Dharma Pawayangan Text B.}

The Dharma Pawayangan B scripting system, following the pairs of Kawi system, with standard spelling guidelines for the Old Javanese-Indonesian Dictionary written by (Zoetmulder \& S.O. Robson, 1994). The translation of this manuscript was carried out by combining the literal (bound) and idiomatic (free) translation methods from the Kawi language into Bahasa Indonesian.

The transliteration of the script from Balinese letters to Latin letters uses diacritical marks, so as not to blur in reading and meaning, the diacritical marks in question are to be distinguished by writing nya=ñ, nia $=$ nya, Ongkara with hulu candra becomes=on, Ongkara with hulu ricem becomes $=0 \div$. Ongkara with tedong becomes $=$ ôn, Ongkara Brahma without tedong becomes $=$ oǹ. For long vocal marked with top line, such as $=\bar{a}, \overline{1}, \bar{u}$. The writing of Wresastra, Swalalita and Modre characters will be done based on the applied norms and still be transliterated to latin scripts unless it is difficult to do so. In such cases the script will be written in its original Balinese script. Wresastra script such as Sasaga is written as=ç, Sasapa is written as =ś, Gaghora ditulis=gh, Damadhu ditulis=dh, Talatik ditulis=ţ, Tathawa ditulis=th, $\mathrm{Ha}$ in Wresastra is written as =ha, Swalalita vocal script is written as =a, i, u, é, o. Wresastra vocal script is written as $=$ ha, hi, hu, hé, ho, he. Narambat is written as =n, the transliteration does not use capital letters since Balinese script does not use capital letters. Based on these rules, Dharma Pawayangan B script is presented herein.

\section{Cultural Values in Dharma Pawayangan}

\section{a. The Realm of Pawayangan (Shadow Puppet Show) and Padalangan (The Art of} Shadow Puppet Mastery)

Aesthetics, logic, and ethics as a medium of intelligence in conveying the message require physical and spiritual guidance. The guideline in question is Dharma Pewayangan, which includes the terms a) Pewayangan (Shadow Puppet show) and Pedalangan (The Art of Shadow Puppet Mastery), which is a two in one concept that refers to the ability of the puppet master to perform the art of wayang performance. Therefore, the person who will be the mastermind must first learn about it. To understand puppet mastery and wayang, one can study the Dharma Pawayangan or Dharma Padalangan (Anandakusuma, 1986; Gautama \& Sariani, 2009; Sugriwa, 1963; Wicaksana, 2007). The following text illustrates the idea.

//ol/ôý awighnàmastu//ol/iti tingkahing Dharma pwayangan, yan makiré makaryya wayang, iki mantranya, ma, pukulun sang hyang guru rékà çakti, hanggawé wa(DP.1a.1) 
... yang, sang hyang śaraçwati hanggawé wayang, sang hyang kawiçwarà hangawé wayang, hanak nirà bhaghgawàn wiçwakarmmà, oǹ à̀ uǹ maǹ, sutéjà prayojana sutéja sudhà ya namah//o// (DP.1a.2)

yan manurun wayang, ma, hingsun sang hyang wundhagi swakarmmà, lah pasunglap hulap hamanis, tkà raktà//ol/ yan mlaspasin wayang wus mapulas ma,ò̀ aǹ uǹ maǹ, çiwà sa- (DP.1a.3)

ddà çiwà prammàçiwà, yogi çuddàprastistà ya nammàh, sah çiwà prammà çiwa $\div$ sùdhdà haywa sùkśma yànamah//o// brataning dalang, tan wenang hamangan salwirning papuswan (DP.1a.4)

Translation:

Here are the rules in Dharma Pawayangan, when starting to build a wayang, the following is the mantra (spell) "pakulun sang hyang guru reka sakti, membuat wa(1a.1)

yang, Sanghyang Saraswati creates wayang, Sanghyang Kawiswara creates wayang, His son Wiswakarma "ong, ang, ung, mang, suteja prayojana, suteja sudha ya namah (1.a.2)

If you also create wayang, the spell is Hingsun sanghyang wundhagi swakarma, lah pangsunglap-hulap hamanis tka rakta. To spiritually cleanse a newly painted wayang the spell is Ong, ang, mang, siwa sa- (1a.3).

ddha Siwa Paramasiwa, yogi suddhaprastista ya namah, sah Siwa Prama Siwa suddha haywa suksma yanamah. A puppet master is prohibited from eating any form of "papuswan" or heart (1.a.4).

\section{b. Kiwa-têngên in Dharma Pawayangan}

Kiwa-têngên concept in wayang is implemented on the concept of pênêngên which contains white mystical character/spirit, by having the nature of dharma = (virtue, truth). Wayang kiwa is called pangiwa, has a black kawisesan character, is adharma = (evil). The puppet characters that come out from above are part of the gods who are paramartha with a high divine soul, perfect, big-hearted, fair and generous. The form of release from left-right influences (kiwa-têngên) is understanding the teachings of kaparamarthan, kamoksan, namely how Sang Mangku Dalang can increase his purity and escape from the entanglement of the kawisesan establishment so as to achieve kamahardikan.

The wayangs as the actors in the story are displayed on the screen, stacked on either side of the screen. The wayangs that are stacked on the left are the Kauravas and Giants groups and those stacked on the right are the Pandavas, Dwarawati, Pancala and Dewa groups. The wayangs that come out from the left are the Kauravas, and those that come out from the right are the Pandavas while the Gods come out from the top right. Philosophically in Balinese culture it is known as "pengiwa-pênêngên" or left-right, or dharma-adharma, God-asura and so on. Wayangs on the right are the "pênêngên" (têngên = right) they posses the spirit of Kebhatinan Putih (white magic) and the characters adhere to dharma (truth) qualities, believe in God, humane, loyal, honest and fair and are protectors of the truth. While the wayangs on left are the "pengiwa" (kiwa = Left), has the spirit, character of Kawicesan Hitam (black magic), are of adharma (evil) nature, cruel, ruthless, angry, disturbing justice and truth. Meanwhile, what comes out from the top right is the middleman, balanced, does not tend to the right or the left (Sugriwa, 1963).

Two black and white powers (black and white magic) which are generally referred to as "rwa-bhineda" are two different and always contradictory qualities but will never disappear and become one in human life. There are men and women, day and night, good and bad and so on. I Wayan Karji said that the concept of "kiwa-tengen" in Balinese culture is; Pengiwa 
comes from the word kiwa (left) which means bad, rude. While tengen (right) means kindness, subtlety and the like. This concept refers to the bipolar principle called rwabhineda; every thing has a good-bad side, positive-negative. A visual depiction of this teaching can be seen in the poleng cloth that is often draped on statues in Bali. The poleng cloth herein refers to the black and white checkered cloth, not thw red-white or other colors cloth. White is the symbol of purity, virtue, while black is the symbol of filth, evil. Although the two traits are in stark contrast, they are always singular.

lang, prayatnà tmên, sùkşma sùkşmà, yan nora wruhà ring kandha iki, dudu sirà dalang, yan sirà wruhà, ikà ngaran dalang utammà dahat, wnang sirà tumaki-taki $m a-$ (DP.12b.1)

ngwayang, iki ngaran dalang ring sarìrà, hning sùkşmaning dhalang ring pantaranning papusuh, gegadingnya héndhah pélag çwaranyà, sawuwus-wuwus, satutùr-tutùr ja- (DP.12b.2)

ti ngaranya, sùkşmà triwikrammà tingkahnyà, sùkşmàdì yatthà, lwirnya punang wayang pangiwà, mwah wayang panêngên, sammi mulih ring ñali, krêpà, çwatammà, mulih ring têngên, (DP.12b.3).

\section{c. Puppet Master's Ethics According to the Text}

The Puppet Master's ethic is that when starting to create wayang, one must ask permission from the gods so that the work is successful. In creating its derivatives, one must also ask for permission, once it is finished, it must be purified so that the wayang becomes sacred and can be used in wayang performances. Always keeping God or any gods that one worship in one's mind when performing a wayang show. Starting from leaving to perform, by saying a prayer and controlling his breathing. The puppet master must also pay attention to his sitting position to profess his worship to the god he worships even when eating. He must always maintain a good relationship with Sang Hyang Panca Maha Buta.

yan sirà wus wruhà ri kandhà dharmmà pedalangan, kawaçà sirà. yan siràmangan marêp wetan wnang, marêp lor wnang, marêp kidul manggêh wighnà, ngundhang bhù- (DP.1b.1)

ttà kojaranya, marêp kulon amanggih bingung, kojaranya, ikang takśu kàsambenan, samangkanà kramanyà kawruhaknà, suddha dàlang uţàmmà, sakalà (DP.1b.2)

mwang niskalàmanggih hayu, wnang mamét hupah mwah hàngalapang sesantun, hapan panugrahan hidà sang hyang ganà çakti, kawruhaknà Dharmaning papwayangan, utammà (DP.1b.3)

tmên, kunang yan ngwayang ñuddàmalà, tan wênang mamet hupah, hila dahat, tinêmah déning sang hyang tigghà, makwéh pammighnanyà, sekala mwah niskalà,(DP.1b.4)

\section{d. Phrobitions for A Puppet Master}

Pursuant to the Dharma Pawayangan B, puppet masters are not allowed to consume any form of animals' heart.

ddà çiwà prammà çiwà, yogi çuddàprastistà ya nammàh, sah çiwà prammà çidya $\div$ sùdhdà haywa sùkşma yànamah//o// brataning dalang, tan wênang hamangan salwirning papuswan. (DP.1a.4).

kêp halah déning sabdà hacakêp, tutùrré satus cakêp halah dhening bukti sinunggal, mwang bantené satus soroh, halah déning soda hadulang, mangkanà kahu- (DP.28a.1) 
tamanya, sang ngangge kawutaman panugrahan hiki, hanging haywà wérà ring wong lyan, yan sirà langganà mamurug tùr ngawerayang, wnang sirà knà biśàmanya, jah tasmat, wa- (DP.28a.2)

stu ilang kasidhyantà kabeh, matmahan dadi wiśya, hangadakhakên gring salah béddha, makadi cêndhêk tuwuh, mangkanà biśàman hiddà bhaţàrà ring sang ngrangsuk panugrahan hiki (DP.28a.3).

\section{e. A Puppet Master Legitimacy}

A puppet master is allowed to perform a show if he has understood Dharma Pawayangan. After he understood it, he will be blessed with safety. As explained in he following passages.

kawruhaknà, poma, 3, tlas //o// ôý awighnàmàstu //o// iki tutùr Dharma papwayangan, yan sira mahyun sudi ring wayang, wnang hinangge de sang mangku da- (DP.12.a.4) lang, prayatnà tmên, sùkşsma sùkşmà, yan nora wruhà ring kandha iki, dudu sirà dalang, yan sirà wruhà, ikà ngaran dalang utammà dahat, wnang sirà tumaki-taki ma- (DP.12b.1)

ngwayang, iki ngaran dalang ring sarìrà, hning sùkşmaning dhalang ring pantaranning papusuh, gegadingnya héndhah pélag çwaranyà, sawuwus-wuwus, satutùr-tutùr ja- (DP.12b.2).

\section{f. Puppet Master and Puppet Show Equipment}

The Puppet Master and Puppet Show Equipment in form of screen, lamp, the puppet master, wayang, gender (traditional musical instrument) and other exquipment in accordance to the philosophy and metaphor Bhuwana Agung (macrocosmos) and Bhuwana Alit (microcosmos). Accoding to "Dharma Pawayangan" The equipments has the following meanings:

1) Gedebong (Banana tree trunk) symbolizes Pertiwi (Earth)

2) Kelir (Screen) symbolizes the emptyness (sunya $=$ empty)

3) Blencong (Traditional lamp) symbolizes the Sun (Bhuwana Agung) or the universe, human Jiwatma (soul) or Bhuwana Alit.

4) Sanan Kropak tied above the screen symbolizes the Sky

5) Kropak Wayang symbolizes the universe or Bhuwana Agung

6) Lelujuh symbolizes Bone

7) Racik symbolizes the fingers

8) Sarwa Tali symbolizes Muscle/tendons

9) Dalang symbolizes God Almighty

10) Wayang symbolizes God's creation (Bhuwana Agung), human's desire (Bhuwana Alit)

11) Gender symbolizes the world rhyme (Bhuwana Agung) human's soul sound (Bhuwana Alit)

12) Four gender musicians symbolize the four siblings of man:

a) Anggapati - Yeh nyom (amniotic fluid) in desire

b) Mrajapati - Red Blood the caretaker of the crossroad/graveyard

c) Banaspati - Placenta in the forest, river, big rocks

d) Banaspati Raja - Vernix Caseosa the thin film covering newborn babies, resides in big trees.

These are the four siblings or kanda pat as the protectors within the Dalang himself.

13) Two Ketengkongs symbolize akasa (the father) and earth (the mother). 


\section{g. The Theology of Shadow Puppet Master and Shadow Puppet Mastery}

Theology is the knowledge of God, literally means the theory or study of God (Titib,2003:1). In the theology of wayang and Shadow Puppet Mastery, this is described from the concept of nirguna brahman, saguna brahman. Saguna Brahman is described with the concept of Sang Hyang Acintya, and Sang Hyang Iswara as the highest form of God which is free of wordly activities. When in the form of Saguna Brahman as the God in activity with shakti and power it is Sang Hyang Guru Reka, Sang Hyang Kawiswara, dan Bhagawan Wiswakarma, Sang Hyang Catur Lokapala, Bhatara Gana Sakti, and Dewata Nawa Sangha, which appear as the quires such as Delem, Sangut, Werdah, and Twalen, by Sang Mangku Dalang. In the effort to provide the sakti and power to the wayang and the shadow puppet master, the power comes from purusa pradana in the form of Sang Hyang Pasupati which provide power Bhatari di Dalem which provides the taksu, through I Ratu Nyoman Sakti Pengadangan.

t, wnang sor wnang luwīr, paripùrņa yà nàmmaçwahà. kaidhêpanyà, çiwà ring bawu kiwà, saddha çiwà ring bawu tngên, pramaçiwàdwarà, masarìra kabeh (DP.3b.4). caritthà, mangisêp sarwa sastrà ganal mwah halit, ring bwanàgung mwang ring bwanàlit, panunggalaling wayang ring adñànàhning, prammàçiwà $i$ ngkanà, uttammà, prête- (DP.13a.4)

lang, ikà ta kawruhaknà, bhaţàrà çiwà ngadêg ring sang dalang. sang hyang indhra dalang ring uri hi tukang hilih. brahma wiśn,u, ikà dalang srere, nga, makadi hi tukang gendher, ikà (DP.15a.4).

\section{h. Shadow Puppet Master and Wayang Rituals}

Rituals or the ceremonies as delineated in Dharma Pawayangan B, related to inviting the spiritual shadow puppet master in oneself, making wayang, the descedants of wayang, purifying the wayang, purifying the shadow puppet master, preparation for performance, starting the performance, finishing the performance, making the holly water for the wayang and cleansing, pangening-hening, pengrapuh, penyepuh, asking for taksu and kawisesan, and the rest is about additional rituals for medication and health.

dalang, ring bwanàlit//o// pabreśiyan dalang, yan sira mambuh, masisig rumuhun, iki mantranyà, ôn an yaņ śaraçwaţhi suddà sêpattikàyà nàmmah (DP.2a.2)

//o// mêjêk hambuh, ma, on, awagyàya nàmah//o// mambuh, ma, ôm gangga mùrttiya nàmah//o// masuwah, ma, on masurìyang nàmah//o// masiram, ma (DP.2a.3)

on sang hyang śiddhiya nàmah//o// mawuswan, ma, on dhéwà tkàwàhenning//o// marawup, ma, on, aṇ oṇ mrêthà sarwwa ila suddà ya nàmmah//o// (DP.2a.4).

$s$ //o// malih tarpanà sang hyang ringgit, bantênyà tatêbasan, 7 , pras pañnêng, pangulapan pngambeyan, tulung sesayut, hane ring sor pasgêhan (DP.11a.4)

14, tandhing, mabe bawang, huyah harêng, tabuhnyà, yeh, wnang, wrêk, sêgeru, brêm, wnang sambat haknà. iki mantranyà, ma, ih ih sirà kalà pisacchà (DP.11b.1).

\section{i. Penalties for Shadow Puppet Master}

In accordance with the ethical rules regulated in this Puppet Dharma, for the puppeteer who does not obey these rules will find distress and he will find misery and be cursed by Sang Hyang Catur Lokapala, and Sang Hyang Gana Sakti.

kawruhaknà iki panugrahan kabeh, haywa sirà kurang wiwekà, yan sirà tan wruh ring panugrahan hiki, hila dahat, katmah dening bhațàrà, nêmu sangsarà (DP.7b.1) kiţà, haywa lali kengêthaknà, ikang panugrahan, panganggen hi sangkul putih, wnang kanggen de sang mangku dalang //o/l iki tingkah sang dhalang, diyusane (DP.7b.2) 
ngwayang, makire mêlis, sang dalang mwajik dumun, harawup, makàkurah. iki mantran wajik, iki mantran wajik. ma, ih sang hyang sùkşme, hañepśe- (DP.7b.3) p parà lêtuh, nir, tkà nir, nir // mantran (m)rawup, ma, on tirthà pawitra, suddha, nir, nir, 3 //ol/ malih yan makakurah, iki mantranyà, ma, ôn ga- (DP.7b.4).

\section{j. Dharma Pawayangan and the Development of Wayang in the Contemporary Modern Era}

According to Wayan Nardayana, along with the times, wayang performances in Bali still use the Dharma Pwayangan standard. Although it is undeniable that inspiring entertainment is also displayed in wayang shows, especially creative wayang, so that they can survive in the midst of entertainment variety both in society and by electronic media. (Nardayana, 2009).

\section{Conclusion}

Transliteration and translation of the Dharma Pawayangan $B$ text, endeavored to understand the world of wayang. The cultural values contained in this manuscript are instructions for becoming an ideal shadow puppet master, in order to understand the concepts of kiwa-tengen and kaparamartan, respect to Istadewata, not to eat the heart of all kinds of animals, and understand all wayang equipments. Istadevata in the world of wayang is understood in terms of Nirguna, Saguna Brahman and its manifestations, which are worshiped in all wayang performances. This must be obeyed, and if violated, will result in a curse. Along with the development of the era that leads to secularization, however, wayang performances should still be based on the Dharma Pawayangan.

\section{References}

Abdullah, I. T. (1991). Hikayat Meukuta Alam. Jakarta : Intermasa.

Anandakusuma, S. R. (1986). Kamus bahasa bali-indonesia, indonesia-bali. Denpasar: Kayumas.

Dibia, I. W. (2012). Geliat Seni Pertunjukan Bali. Denpasar: Buku Arti.

Djamaris, E. (2002). Metode Penelitian Filologi. Jakarta: Manasco.

Gautama, W. B., \& Sariani, N. W. (2009). Kamus bahasa bali-indonesia, indonesia-bali. Surabaya: Paramita.

Hendro, D. (2013). Komodifikasi Seni Pertunjukan Wayang Dalam Perspektif Budaya Pop Dalam Wayang. Jurnal Ilmiah Seni Pewayangan, 12(1), 1-10.

Jones, R. (1980). Review article: Problems of editing malay's texts discussed with reference of the hikayat muhammad hanafiyyah. Archipel, 20, 121-127.

Kratz, E. (1981). The Editting Of Malay Manuscripts And Textual Criticism. Journal of the Humanities and Social Sciences of Southeast Asia, 137(2), 229-243.

Kusumayanti, A. H. (2012). Srimpi Nadheng Putri: Transformasi Naskah Menjadi Bentuk Tari Tradisi Pura Pakualaman. Yogyakarta: Manasa.

Moleong, L. J. (2005). Metodologi Penelitian Kualitatif. Bandung: Remaja Rosdakarya.

Muhadjir, N. (2002). Metode Penelitian Kualitatif. Yogyakarta: Rake Sarasin.

Mulyana, D. (2000). Metode Penelitian Kualitatif, Paradigma Baru Ilmu Komunikasi Dan Ilmu Sosial Lainnya. Bandung: Remaja Rosdakarya.

Ratna, I. (2006). Teori, Metode, Dan Teknik Penelitian Sastra. Yogyakarta: Pustaka Pelajar.

Robson, S. (1994). Prinsip-Prinsip Filologi Indonesia. Jakarta: RUL.

Sedyawati, E. (1997). Naskah dan Pengkajiannya. Jakarta: Masyarakat Pernaskahan Nusantara. 
Seramasara, I. G. (2019). Wayang Sebagai Media Komunikasi Simbolik Perilaku Manusia Dalam Praktek Budaya Dan Agama Di Bali. Mudra: Jurnal Seni Budaya, 34(1), 8086.

Soeratno, S. C. (1991). Hikayat Iskandar Zulkarnain. Jakarta: Balai Pustaka.

Sugiyono. (2007). Metode Penelitian Pendidikan, Pendekatan Kuantitatif, Kualitatif, dan R \& $D$. Bandung: Alfabeta.

Sugriwa, I. G. (1963). Ilmu Pedalangan/Pewayangan. Denpasar: Kanisius.

Teeuw, A. (1988). Sastra dan Ilmu Sastra: Pengantar Teori Sastra. Bandung: Dunia Pustaka Jaya.

Wicaksana, I. D. (2007). Wayang Sapuh Leger: Makna dan Fungsinya Bagi Masyarakat Bali. Denpasar: Pustaka Bali Post.

Zoetmulder, P. J., \& Robson, S. (1994). Kamus Jawa Kuna-Indonesia. Jakarta: Gramedia Pustaka Utama. 